\title{
Writing and Music: Album Liner Notes
}

\author{
Dean L. Biron, independent scholar
}

\section{'Covering' music}

The 2005 edition of Hoffman and Ferstler's Encyclopedia of Recorded Sound includes the following 60-word entry on the record sleeve:

\footnotetext{
The jacket or envelope used for protecting, storing or marketing a disc recording; also known as a slipcase or a record cover. Usually the material is paper or cardboard. Often there is a second envelope inside the sleeve, made of paper or mylar, intended to give the surface additional protection. Sleeves may do more harm than good to their records, however.' (2005: 1001)
}

The reader is then directed to a 6 page entry titled 'Preservation of Sound Recordings,' where information is provided on the proper storing and maintenance of phonographic records, magnetic tape and compact discs. Apart from an allowance for marketing practices, here the album sleeve or liner is considered little more than a carriage device - one of dubious function - for the primary product contained within. Yet without needing to deny that the fundamental purpose of an LP record or compact disc is to store music, it is nevertheless true that the accompanying sleeve or (in the case of the CD) booklet has, over the course of the past few decades, developed something of an aura of its own.

Originally, record sleeves were blank with a doughnut-like hole in the middle through which the central label of the vinyl could be read. This typically contained crucial information for the purchaser, namely the title of the disc and details of the recording artist and publisher. Over time, however, as shellac-based 78 rpm records were 
superseded by vinyl 33 1/3 LPs (Elborough 2008: 23), more advanced cover designs themselves became spaces for art: for painting and drawing; for photography; for written expression (including song lyrics). ${ }^{1}$ This seems a quite natural evolution in light of the fact that the different aesthetic forms have always interacted with, and borrowed from, each other, a process that only became more palpable in the latter half of the twentieth century.

Jonathan Kramer cites intertextuality—characteristic of multi-faceted texts that disrupt received ideas of source and genre-as one of the distinguishing traits of music in the postmodern period. Yet the interaction of multiple aesthetics with the prima facie sound-based artefact of the record album evokes what might more appropriately be termed a 'polytextuality' (ostensibly a musicological term meaning 'many-texted'). Polytextuality is, in turn, reminiscent of the Derridian concepts of 'tympan' and 'parergon.' The former is suggestive of a softening of boundaries which allows ostensibly central and marginal texts to be read together in a complimentary fashion (Derrida 1982), while the latter alludes to a frame that accompanies and merges into the work, rather than merely encircling or enclosing it (Derrida 1987). ${ }^{2}$

\section{Music, art, film, literature}

The jazz music of the $20^{\text {th }}$ century provides numerous salient examples of generic crosspollination. For instance, composers such as Ornette Coleman and Joe Harriot overtly connected their work with modern art. The former included a reproduction of a Jackson Pollock picture called White Light with his 1961 album Free Jazz, the improvisational nature of the music bearing close resemblance to Pollock’s own inimitable technique. The latter used, to similar effect, a remarkable painting by the lesser known Yvonne de Miranda for the cover of his Abstract (1962). Inspiration also travelled in the other direction, as most famously depicted in Piet Mondrian's final paintings, Broadway Boogie Woogie and Victory Boogie Woogie.

\footnotetext{
${ }^{1}$ Elsewhere, Elborough says that the 'swishly packaged' LP allowed for 'entirely new, ingenious combinations of sounds, printed text and illustrations that would dovetail perfectly with the needs of the epoch' (2008: 46). If such sentiments evoke a subset of consumers seeking more in-depth, more informative, and more enduring aesthetic artefacts, then the equally-revolutionary 7-inch vinyl single arguably served a different style of music consumption focused more upon immediacy and disposability (the purpose and format of the single, for example, being generally antithetical to detailed sleeve notes). 2 The tympan or tympanum is a type of musical drum; the tympanum is also the middle ear cavity or eardrum. In art, the parergon refers to an accessory or augmentation subordinate to the main work.
} 
Film, as well, exhibited a strong association with jazz. Duke Ellington famously contributed an appropriately racy, fast-paced soundtrack to Otto Preminger’s 1959 courtroom drama Anatomy of a Murder, while Miles Davis provided a haunting musical accompaniment to Louis Malle's Ascenseur pour l'échafaud (Lift to the Scaffold) a year earlier. And the same can be said for literature, from F. Scott Fitzgerald's coining of ‘the jazz age’ to novels such as Michael Ondaatje’s Coming Through Slaughter (1976) and Geoff Dyer's But Beautiful (1991), both fictional representations of jazz legends, as well as Toni Morrison’s Jazz (1992), constructed in the manner of a jazz composition.

Undoubtedly writing has had the most fraught relationship with music. Consider this statement by Ornette Coleman, taken from the liner notes of his 1960 album Change of the Century: 'In music, the only thing that matters is whether you feel it or not. You can't intellectualise music; to reduce it analytically is often to reduce it to nothing very important. It is only in terms of emotional response that I can judge whether what we are doing is successful or not [original italics].’ Here Coleman touches upon the old argument concerning the 'presumed autonomous “thingness” of works of music,' as Christopher Small puts it (1998: 4)—the musical object in which all meaning resides, self-contained, waiting for 'the ideal perceiver to draw it out' (5). In thrall of this idea, the cliché (usually attributed to Elvis Costello) that writing about music is like dancing about architecture- - in other words, that writing about music is a pointless occupation to undertake - continues to hold currency. This is despite the fact that many of those who recycle the line, even those who believe it to reveal an inalienable truth, continue on writing (about music) as though the paradox has escaped them. ${ }^{3}$

But a question arises here: why writing about music? The preposition 'about' means appertaining to, in connection with, concerning, or in reference to. Derrida alludes to this problem when, in an interview with Derek Attridge, he speaks of the 'serious question' of the literary texts that he writes 'about, with, toward, for ... what should one say?' Writing and music, it can be suggested, are both languages-languages that are separate and detached, but that nonetheless often intersect. Thus a subtle distinction is all that is required to lay the dancing about architecture chestnut to rest once and for all, for while written language must inevitably fall short (were it to try) of capturing the

\footnotetext{
${ }^{3}$ This appears at the beginning of Stephen Ryan's nonetheless lengthy paper on postmodern Irish music: 'As Elvis Costello's quote [...] suggests, any attempt to rationalise, analyse or intellectualise music is bound to fail. By its very nature, music is not suited to a written discourse' (1997).
} 
essence of music (it can never actually be what it is describing), what it can do is forcefully and eloquently express how people respond to musical experiences (it being the best descriptive tool we have).

The stated central goal of Peter Dayan's 2006 Music Writing Literature: From Sand via Debussy to Derrida, is to engender a 'new appreciation ... of the singularity that literature and music share’ (2006: 133). Dayan makes the point that for the French literary figures Mallarmé and Proust, 'writing about any kind of art could only be worth its salt to the extent that it ineluctably became art' (ix [original italics]). Therefore, it might also be said that in the process of becoming (or trying to become) art, writing to a great extent becomes about itself. Music writing is first and foremost about the art of writing; as the critic Robert Christgau has said, 'writing about music is writing first' (2005). Or, to put it another way, it is possible to write about music quite simply because it is possible to write. ${ }^{4}$

\section{The evolution of liner note writing}

So far as the intertwining of music and literature goes, this is especially notable in the phenomenon of album liner or sleeve notes. In one of the few in-depth discussions on the matter, Colin Symes (speaking specifically of classical music) claims that such notes 'occupy a modal universe different from that of the record, and much of their efficacy as a textual form depends on their capacity to accord with its contents and minimise any distortion that might flow from transferring between "modes of meaning”' (2004: 124). Here Symes speaks of music very much as a stream of information-and information of a transcendent nature at that-travelling from the composer (likely a genius) to the listener (to some extent a neophyte). Returning to Ornette Coleman’s statement about Change of the Century, it is interesting that this seems precisely the point around which the concept of ineffability surrounding music starts to get muddy.

Prominent in classical, ethnographic and jazz recordings up until the 1960s were liner notes that tended to instruct the listener in a didactic way, imparting what Symes calls the 'inside story of the music' (2004: 126). But with the advent of pop and rock in particular, the circumstances surrounding the reception of music began to alter, to

\footnotetext{
${ }^{4}$ Just as it is possible to dance about architecture because it is possible to dance. Further eroding the worth of the cliché, at the 1931 Beaux Arts costume ball in Manhattan, several noted architects came actually dressed as the skyscrapers they had designed (Gray 2006).
} 
become arguably less didactic, less formal. Coleman himself says that on Change of the Century his band is trying to 'break through to a new, freer conception of music, one that departs from all that is standard and cliché in modern jazz.' There is a tension here between tradition and innovation, the idea that the music can transcend formula and genre, but ways of talking or writing about it supposedly cannot. It seems paradoxical, then, that the sleeve notes for many jazz recordings of the time were particularly innovative, ${ }^{5}$ despite Coleman's apparent blind spot as to the aptness of writing 'about, with, toward [or] for' music.

Indeed, the liner note essay might be said to have come of age in the early 1960s, as the emergence of the album as key rock music artefact coincided with the increasingly stylish packages that accompanied jazz LPs released on labels such as Blue Note and Impulse. In the former instance, experiments in liner note literature appeared with LPs by many of the major Anglo-American artists of the period. The Rolling Stones UK release Rolling Stones II (1965), included an original essay in the counter-cultural mode by producer Andrew Loog Oldham, in which he suggested (presumably tongue-incheek) that people resort to crime in order to obtain money to buy the record.

Conversely, the back cover of the Beach Boys’ Summer Days (and Summer Nights!), from the same year, presented a selection of friendly fan letters from each member of the band. Perhaps most notable, however, was the sleeve writing of Bob Dylan. While his music was breaking new ground in terms of lyrical style, Dylan was supplementing many of his epic 1960s LPs with extended bouts of either poetry (as on Another Side of Bob Dylan [1964]) or prose (as on Bringing it all Back Home [1965]).

So far as jazz music is concerned, no more unique a case could be cited than that of composer Charles Mingus's record The Black Saint and the Sinner Lady (1963). ${ }^{6}$ To accompany his own acerbic notes, which to an extent echo Coleman in their berating of the critic-musician who 'brainwash[es] innocent little people who don't know that if you're going to like something that's beautiful no one can tell you how if it don't just happen,' Mingus commissioned his clinical psychologist Edmund Pollock to write a further essay for inclusion on the inner sleeve. Pollock begins:

\footnotetext{
${ }^{5}$ A number of salient examples from jazz recordings of the 1950s and 1960s are collected in Tom Piazza’s Setting the Tempo: Fifty Years of Great Jazz Liner Notes (1996).

${ }^{6}$ Its jazz credentials notwithstanding, the label originally altered its customary sleeve-catchphrase to read 'the new wave of folk is on Impulse.'
} 
When Mr Mingus first asked me to write a review of the music he composed for this record, I was astonished and told him so. I said that I thought I was competent enough as a psychologist but that my interest in music was only average and without any technical background. $\mathrm{Mr}$ Mingus laughed and said he didn't care, and if I heard his music I'd understand.

Following on from this extraordinary example, the next section will detail some of the different liner note styles that developed in the latter part of the $20^{\text {th }}$ century. But first, the various approaches I will be discussing need to be further situated within two wider general frameworks: format and authorship. The original LP sleeve provided, as Elborough (2008: 6) notes, a 'canvas for an entirely new visual language to blossom.' This canvas soon grew with the introduction of gatefold sleeves, which opened out to reveal a mid-section upon which further photographs, lyrics or written text could be placed. Conversely, for the compact cassette tape format-prominent in the 1970s and 1980s — such material would often (though not always) be reduced or excluded altogether due to space constraints. The later compact disc design, while reducing the actual dimensions of the cover, evolved booklet-style inserts with ample space for supplementary information, including lengthy liner notes. The phenomenon of reissuing/remastering earlier LPs in CD format further led to the juxtaposing of original liner notes with an updated essay, one which provides hindsight commentary on the recording and musician in question. ${ }^{7}$ Essentially, sleeve writing has over time expanded and contracted in line with the different formats available; as such, while its very existence appears seriously threatened by the widespread shift to digitally compressed audio, it is equally likely that musicians and critics will adapt other ways, such as album-specific web-pages, to connect music and written text. ${ }^{8}$

Stylistically, the story of the liner note is further bound up with the notion of authorship. Notwithstanding examples such as The Black Saint and the Sinner Lady, sleeve writing has historically been dominated by two types of writer: the composer and the critic. That is not to say, however, that textual style is ever necessarily reliant upon the identity of the author. As we will see from the examples to follow, composers sometimes provide sleeve literature for which the goal is not so obviously to 'sell' their musical product, while neither are the intentions of critics (whether journalistic, academic, or

\footnotetext{
${ }^{7}$ The subsequent CD version of Ascenseur pour l'échafaud (issued in 1988) is a good example of this.

${ }^{8}$ While the aura of the original LP or CD object seems much reduced by the computerised carriage device, it might be remembered that, so far as liner notes and cover art are concerned, these were likely to be similarly absent from the home-made cassette tapes which were prominent in music collecting in the late $20^{\text {th }}$ century.
} 
otherwise) always clearly signposted. The dynamic and unpredictable relationship between author, text and recipient, combined with the polytextuality of the music album format, ultimately defeats any received notions of purpose or utility and allows for liner notes to be considered on the basis of their literary qualities alone. ${ }^{9}$ What can be more clearly delineated—so far as the authorship of liner notes in classical, jazz, rock, pop and ethnographic music is concerned-is an embedded gender imbalance in that such writing, as with music criticism generally (McLeod 2002: 94), has been the almost exclusive domain of male authors. As a final point, it should be emphasised that album liner notes can be regarded as appropriate to some circumstances but not others; certainly, the option taken by the likes of New Zealander Michael Morley with his band Gate, on albums such as Monolake (1997), which is to often eschew any form of identifying details or extraneous written information on the record sleeve whatsoever, is an equally valid one.

\section{Styles of liner note writing}

It is possible to identify at least five prominent broad (yet at times intertwining) varieties of liner note literature over the past few decades. The point here is not to insist that the examples referred to, along with the music they accompany, constitute great art (though I happen to believe that the majority of them do). ${ }^{10}$ Rather, it is to argue that they help show liner note literature worthy of being considered part of the overall aesthetic experience attached to music, amounting to more than just what Symes refers to as a 'framing device [that places] inverted commas around objects considered worthy of extended contemplation' (2004: 124), though they may well operate in that way as well.

\section{The Literary Liner Note}

In the best examples of the literary liner note, contributors fashion art from writing that

\footnotetext{
${ }^{9}$ Henry James's famed prefaces are somewhat analogous to sleeve writing in having the air of what Gérard Genette (1997: 1-2) calls the 'paratext': essentially texts of a 'threshold' or 'fringe' nature in comparison to the primary text. Nonetheless, William Goetz, in his analysis of James's prefaces, crucially alludes to them as being of complex utility (not merely extensions of the novels; not simply commentaries on them), suggesting that they might first be taken as 'literary work in their own right' (1979: 333). A similar case can, I would suggest, be made for the album liner note.

${ }^{10}$ Any arbitrariness in the selections I have chosen for discussion is mitigated by the pleasure of espousing literary worth in a cross-section of texts; in fact, Elborough posits an equivalent explanation in his selections in his celebration of the LP record: 'This is a magpie's book ... the reasons some albums or events are mentioned veer from the wilfully arbitrary to the breathtakingly callow. It barely scratches the surface of the LP, but what more can anyone do?' (2008: 17).
} 
is inspired by music. Miles Davis’s breakthrough 1970 electric album, Bitches Brew, truly was a work of aesthetic brilliance on several levels, including the spectacular cover painting by Mati Klarwein and the superb accompanying narrative by critic Ralph Gleason. With the benefit of hindsight, Richard Cook and Brian Morton’s Penguin Guide to Jazz on CD calls Bitches Brew 'a gigantic torso of burstingly noisy music that absolutely refuses to resolve itself under any recognised guise' (2000: 378). Gleason wrote his liner note essay not knowing the impact the record was going to have upon future generations of listeners, yet his words are prophetic. They are also deeply philosophical, articulating perfectly how new artistic achievements should stand alongside, rather than usurp, past ones:

It will never be the same again now, after In a Silent Way and Bitches Brew ... how can it ever be the same? I don't mean you can't listen to Ben. How silly. We can always listen to Ben play Funny Valentine until the end of the world and it will always be beautiful ... it's not more beautiful. Just different ... a new kind of beauty ... a different beauty ... the other beauty is still beauty. (Bitches Brew, 1970)

Wielding a very different prose style, but writing with just as much passion and foresight, Greil Marcus's liner notes to the Bob Dylan and the Band album The Basement Tapes (recorded in 1967 but not released until 1975) form the prototype for what would later become a book-length study, The Old Weird America (1997). Reading his essay, one can sense more than just Marcus's excitement about how amazing the album sounds; coming through as strongly is the idea that this music, which he calls 'as slick as a barbed wire fence [and] no more dated than the weather,' has engendered in him the desire to write. In this undertaking he was likely influenced by the original notes Harry Smith appended to his Anthology of American Folk Music collection of 1952, a recording Marcus contends is an important precursor to The Basement Tapes.

\section{The Tangential Liner Note}

A second style of liner note is the tangential, comprising essays that tend also to have literary pretentions while wandering off in directions not necessarily suggested by the music contained within. A case in point is guitarist John Fahey’s classic 1966 album Days Have Gone By, supplemented by words from the composer himself under the pseudonym of Elijah P. Lovejoy. This bizarre tale, in the manner of American literary postmodernists of the period such as John Barth and Thomas Pynchon, has Lovejoy encountering characters like Whooppie John Wilfahart and Tree Sloth Man in a 
meandering tale that eventually gets down to the business of explaining how the recording sessions for Days Have Gone By unfolded. Indeed, Fahey became something of a sleeve writing pioneer in the 1960s, using liner notes to invent personas that blurred the boundaries between composer and listener, scholar and neophyte.

Another example is Galaxie 500’s On Fire (1989), where on the back cover engineer and producer Kramer digresses with a rambling piece on the great Chicago fire and watching the Disney show as a child, a story that, astutely, only in its final sentence becomes an exaltation of the band in question:

\begin{abstract}
Sometimes I'd see Walt himself, sometimes Mickey or Goofy. But sometimes I'd see a thousand bright blue caribou racing a dust storm to the finish line, neck and neck like nature's own Indy 500. Flesh and blood against the elements. And I remember wondering to myself, 'why are they racing?' Then one fine day I understood why the race took place. It was because the hairs on those caribou's necks were being tickled by the instinctual knowledge of a fire raging not too far away and most certainly headed this way. Humans often get the same feeling ... like an oddly warm breeze malevolently fuelled by the maddening flames behind it. Come ride the fiery breeze of Galaxie 500! (On Fire, 1989)
\end{abstract}

\title{
The Expository Liner Note
}

A further variety is the expository style: these involve discussions based on how the music came into being that are, in the best instances, reader-friendly and without the didacticism traditionally associated with explanations of complex musical compositions. One of the finest exponents of the expository approach is Brian Eno. For his 1982 album Ambient IV: On Land, for instance, Eno constructs a brief but fascinating essay that melds the evolution of his 'environmental' recording techniques, and the listing of various musical and filmic influences, with redolent passages on the philosophical and emotional underpinnings of his music, especially the important role played by memory.

Of the track titled 'Lantern Marsh,' he writes:

Lantern Marsh, for example, is a place only a few miles from where I grew up in East Anglia, but my experience of it derives not from having visited it (although I most certainly did) but from having subsequently seen it on a map and imagining where and what it might be. We feel affinities not only with the past, but also with futures that didn't materialise, and with the other variations of the present that we suspect run parallel to the one we have agreed to live in.

(Ambient IV: On Land, 1982)

There are many other fascinating examples in this vein. For the 1993 re-issue of his Jesus' Blood Never Failed Me Yet — coincidentally first released on Eno’s Obscure label in 1975-Gavin Bryars tells of how he came across the singing tramp whose voice underpins the work. It can be contended that the experience of hearing this music is 
greatly enhanced by the listener being able to read the composer's touching account of how the project came to be realised.

Another is Australian sound artist Darrin Verhagen's 1997 release Soft Ash, subtitled 'seven treatments of lethal atmospheric inversions (with a drifting narrative sense).' Verhagen's annotations for each of the tracks combine scene-setting details with advice on the source of the musical treatments. For 'MIC,' concerning the 1984 Union Carbide disaster in Bhopal, India, the listener is provided with the following information:

shortly after midnight tons of methyl isocynate were released from a storage tank at Union Carbide, spreading as a fog-like cloud over a large, highly populated area. More than 2000 direct deaths reported. Pollutant-MIC ... sounds constructed predominately from tape hiss from badly mastered recordings of Indian music ... recommended listening volume: medium/medium high. (Soft Ash, 1997)

\section{The Propagandist Liner Note}

For this style of liner note, artists use the available space on the sleeve to espouse political or quasi-political views that may or may not also be prevalent in the accompanying music. In the notorious case of Funkadelic's Maggot Brain LP, released in 1971, the reader is confronted with an anonymous, somewhat unsettling creed attributed to the Process Church of the Final Judgement (an organisation with supposed links to Charles Manson): 'And do we know that wars and rumours of wars mount up in an ascending spiral of violence and potential violence, as the fear in the hearts of men intensifies? Do we know that strife of every kind increases as hatred, resentment, jealousy and prejudice increase, and that all of these stem from one thing only: fear?' (Maggot Brain, 1971).

More recently, the line in ideological statements has been taken up by the likes of Canadians Godspeed You! Black Emperor (formerly Godspeed You Black Emperor!). For their memorable 1998 release $f \# a \# \infty$, formidable orchestrations and fragments of spoken word-' 'we're trapped in the belly of this horrible machine, and the machine is bleeding to death'; 'the preacher man says it’s the end of time, says America's rivers are running dry'-mingle with desolate photographs, a copy of a grim Petition for Divorce form ('no efforts to reconcile have been made'), and an anonymous written creed called 'The Story thus Far' ('we've been ploughing our little field up here for a couple of years now, but the yard is still filled w/rocks \& dust \& sick trees ... so we bide our time’), all 
of which hints at the band as fraught backwoods fugitives. ${ }^{11}$

Another proselytising amalgam can be found on John Zorn's Kristallnacht (1993). Here, the tragedy of the 'night of broken glass,' the November 1938 Nazi anti-Semitic crackdown across Germany and Austria, is evoked by a combination of melancholy klezmer music, a track ('Never Again') that recreates the breaking glass sound of the title (in a manner that Zorn warns may cause ‘temporary or permanent ear damage’), a photograph of a Nazi sculpture alongside another of the corpse of a holocaust victim, and three powerful written pieces from novelist Lynne Tillman, poet Edmond Jabès and playwright Richard Foreman respectively.

\section{The Retrospective Liner Note}

Perhaps the most familiar of all liner note styles is the retrospective, germane to compilations and re-releases calling attention to the careers of both major and obscure artists and scenes. In particular, this format affords the opportunity for critics to reaffirm or re-imagine the place of favoured musicians and bands in the context of a wider musical history. Guy Blackman's notes to the 2006 CD Can't Stop it II: Australian Post-Punk 1979-1984, for instance, achieve this by engendering a particularly Antipodean notion of nostalgia, recalling the exploits of the Systematics, Scapa Flow and other bands who burned briefly and not so very brightly in the 'cracks and fissures' of a period dominated by pub rock and new wave. Similarly, Guy Marc Hinat's studious notes to the 2008 compilation, Oh, Run into Me, but Don't Hurt Me: Female Blues Singers Rarities 1923-1930, help position unsung artists like Virginia Liston and Jenny Pope within the authentic history of early $20^{\text {th }}$ century American blues music.

Of course, since the 1980s the rise in interest in so-called 'world music' has seen an outpouring of retrospective releases that attempt to package entire musical cultures for consumption by curious Westerners. Records of the nature of Ancient Heart: Mandinka and Fulani Music of the Gambia (1990), annotated for Bill Laswell's Axiom label by Robert Browning of the World Music Institute, and Women of Istanbul (1998), including in-depth historical analysis by Harold G. Hagopian, provide further evidence

\footnotetext{
${ }^{11}$ In an article in the British experimental music publication The Wire around the time $f \# a \# \infty$ was released, band member David Bryant says: 'We try to make music that holds some sort of emotional power ... to make a record about hope and enduring in the face of real economic and existential uncertainty' (Keenan 1998: 14).
} 
of how music and writing can combine in the formulation of finely-crafted and compelling aesthetic productions.

Sometimes, the format allows for musicians to reflect back on their own earlier work. A specific take on the retrospective essay is the fragmentary, track-by-track account, which to my knowledge first appeared on the 1978 Neil Young compilation album Decade. Here, the inner sleeve features Young's own brief notes on the genesis of each of the 35 tracks included, which taken together provide a chronology of his career to that point. One of the best known of these excerpts refers to 'Ohio,' which Young composed in response to the Kent State University massacre of 1970: 'It is still hard to believe I had to write this song. It is ironic that I capitalised on the death of those American students. Probably the biggest lesson ever learned at an American place of learning' (Decade, 1978).

\section{Writing and music belong together}

There is a great amount of significant detail in the liner note examples described herefrom Darrin Verhagen's observations on tragic airborne toxic events, to Greil Marcus's studied analysis of the impact of Dylan and the Band's Big Pink sessions, to Guy Marc Hinat's testimony on the careers of long-lost female blues singers. Whether or not that detail closely articulates what is contained in the music is not so much the point. What is important is that discourses on music need not, as they regularly are in critical analysis, be restricted to a focus upon specific musical texts, genres and scenes. How different texts, genres and scenes relate to each other, and how music itself intersects with other art forms, including literature, is just as significant.

This paper does not provide a definitive history of liner note writing. Rather, the goal is to encourage liner notes to be considered a valuable part of the overall experience of interacting with recorded music - to help show that writing and music, like dancing and architecture, can in the right circumstances be perfectly appropriate bedfellows. That music engenders literature should, after all, be considered a quite natural state of affairs: as Ralph Gleason, referring to the impact Bitches Brew had upon him, puts it, 'if I could I would write a novel about it, full of life and scenes and people and blood and sweat and love.' 


\section{Acknowledgements}

This essay is an extended version of a presentation given at the Griffith University Centre for Cultural Research 'Popular Music and Everyday Life' Symposium of 2009. I would like to thank Professor Andy Bennett and the symposium participants, Tony Mitchell of UTS, my partner Suzie Gibson, and the anonymous reviewers for their helpful comments.

The essay is dedicated to Luci Biron-Gibson (2009-2010), who tried so hard to live.

\section{Reference List}

Christgau, R. 2005, 'Writing about Music is Writing First,' Popular Music, vol. 24, no. 3, 415-421. Cook, R. \& Morton, B. (eds) 2000, The Penguin Guide to Jazz on CD (5 ${ }^{\text {th }}$ Ed.). Penguin, London. Dayan, P. 2006, Music Writing Literature: From Sand via Debussy to Derrida. Ashgate. Burlington, VT. Derrida, J. 1982, Margins of Philosophy, trans. A. Bass, University of Chicago Press, Chicago. 1987, The Truth in Painting, trans. G. Bennington \& I. McLeod. University of Chicago Press, Chicago. 1992, Acts of Literature. ed. D. Attridge. Routledge, New York.

Dyer, G. 1991, But Beautiful: A Book about Jazz. Cape, London.

Elborough, T. 2008, The Long-Player Goodbye: The Album from Vinyl to iPod and Back Again. Sceptre, London.

Genette, G. 1997, Paratexts: Thresholds of Interpretation. trans. J. Lewin. Cambridge University Press, New York.

Goetz, W. 1979, 'Criticism and Autobiography in James’s Prefaces,' American Literature, vol. 51, no. 3, 333-348.

Gray, C. 2006, ‘A New Age of Architecture Ushered in Financial Gloom,’ New York Times, 1 January, 2. Hoffman, F. \& Ferstler, H. (eds) 2005, Encyclopedia of Recorded Sound (2 ${ }^{\text {nd }}$ ed.). Routledge, New York.

Keenan, D. 1998, 'Godspeed You Black Emperor!: Back from Infinity,' The Wire: Adventures in Modern Music, September, 14.

Kramer, J. 2002, 'The Nature and Origins of Musical Postmodernism,' in Postmodern Music, Postmodern Thought, (eds) J. Lochhead \& J. Auner. Routledge, London, 13-33.

Malle, L. (dir.) 1958, Ascenseur pour l'échafaud (Lift to the Scaffold), Nouvelles Éditions de Films.

McLeod, K. 2002, 'Between Rock and a Hard Place: Gender and Rock Criticism,' in Pop Music and the Press, (ed.) S. Jones. Temple University Press, Philadelphia, 93-113.

Marcus, G. 1997, The Old, Weird America: The World of Bob Dylan's Basement Tapes. Picador, New York.

Morrison, T. 1992, Jazz. Knopf, New York.

Ondaatje, M. 1976, Coming Through Slaughter. Norton, New York.

Piazza, T. ed. 1996, Setting the Tempo: Fifty Years of Great Jazz Liner Notes. Anchor, New York. Preminger, O. (dir.) 1959, Anatomy of a Murder, Carlyle Productions.

Ryan, S. 1997, 'Dancing About Architecture: Postmodernism and Irish Popular Music,' Irish Communications Review, vol. 7. Online, available: http://www.icr.dit.ie/ [accessed 4 September 2011].

Small, C. 1998, Musicking: The Meanings of Performing and Listening. Wesleyan University Press. Middletown, CT.

Symes, C. 2004, Setting the Record Straight: A Material History of Classical Recording. Wesleyan University Press, Middletown, CT.

\section{Discography}

The Beach Boys, Summer Days (and Summer Nights!), Capitol, 1965.

Gavin Bryars, Jesus' Blood Never Failed me Yet, Point Music, 1993.

Ornette Coleman, Change of the Century, Atlantic, 1960. Free Jazz, Atlantic, 1961.

Miles Davis, Ascenseur pour l'échafaud, Fontana, 1958. Bitches Brew, Columbia, 1970. 
Bob Dylan, Another Side of Bob Dylan, Columbia, 1965.

Bringing it All Back Home, Columbia, 1965.

Bob Dylan \& the Band, The Basement Tapes, Columbia, 1975.

Duke Ellington, Anatomy of a Murder, Columbia, 1959.

Brian Eno, Ambient IV: On Land, EG, 1982.

John Fahey, Days Have Gone By (Vol. 6), Takoma, 1967.

Funkadelic, Maggot Brain, Westbound, 1971.

Galaxie 500, On Fire, Rough Trade, 1989.

Gate, Monolake, Table of the Elements, 1997.

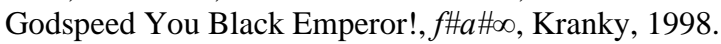

The Joe Harriot Quintet, Abstract, Redial, 1962.

Charles Mingus, The Black Saint and the Sinner Lady, Impulse, 1963.

The Rolling Stones, The Rolling Stones II, Decca, 1965.

Various Artists, Ancient Heart: Mandinka and Fulani Music of the Gambia, Axiom, 1990.

Various Artists, Anthology of American Folk Music, Smithsonian, 1997.

Various Artsits, Women of Istanbul, Traditional Crossroads, 1998.

Various Artists, Can't Stop it, Vol. II: Australian Postpunk 1979-1984, Chapter Music, 2006.

Various Artists, Oh, Run into Me, but Don't Hurt Me: Female Blues Singers Rarities 1923-1930, Subrosa, 2008.

Darrin Verhagen, Soft Ash, Dorobo, 1997.

Neil Young, Decade, Reprise, 1978.

John Zorn, Kristallnacht, Tzadik, 1993. 